Ballestero S., A. (2014). Theory from the South or, How Euro-America Is Evolving toward Africa Jean Comaroff and John L. Comaroff. (Boulder, CO: Paradigm Publishers, 2012). PoLAR: Political and Legal Anthropology

Review, 37(1), 189-191. doi:10.1111/plar.12061

\title{
Theory from the South or, How Euro-America Is Evolving toward Africa Jean Comaroff and John L. Comaroff. (Boulder, CO: Paradigm Publishers, 2012)
}

\author{
Andrea S. Ballestero, Rice University [ORCID: 0000-0001-7692-0514]
}

Theory from the South is a provocative book intended to add an element of play in the evolutionary and progress-based rhetoric that undergirds political projects around the world. The authors take issue with the entrenched colonial paradigm in which post-colonies continue to change toward models and images of the North to suggest that in fact, the inverse is true. Africa, Latin America and Asia look more like the future, than the past. The authors do not quite make an argument of reversed linearity, yet they are not completely beyond that logic, and so they pose that the world is witnessing an eastward and southward dislocation of the most dynamic and innovative centers of value production. Political geographies of core and periphery, they assert, are increasingly unable to explain this geographic shift (p. 7). The authors examine this dislocation through seven chapters that focus on personhood, liberalism, democracy, the politics of the body, history, and the paradoxes of borders. Each chapter offers a textured example of forewarning, anticipation, and foreshadowing of the North by Africa.

As part of the authors' larger intellectual project of going beyond documentation of difference into the production of explanations, the book offers at least three major [End Page 189] axes to examine foreshadowing and lagging behind as historical processes. With the erudition and style that characterizes their work, the authors offer a view toward the near past and the near future in connection to longer histories whose condition of possibility is the making of colonial and postcolonial Africa. The three axes around which I organize the Comaroffs' explorations are what they might call the grounds for a "theoretical practice that is not reducible to the micro-local." (p. 48) These axes are transversal to the book and I pose them as heuristics for the nuanced and complex conjunctures the chapters explore. This review merely flags them with the purpose of highlighting some of their core arguments. 
Firstly, Theory from the South argues that we are in an era of politics done otherwise. It is not that politics are completely obviated but they have taken the form of the market, the form of the judiciary, and even the shape of human bodies as part of globalized health epidemics such as HIV/AIDS. Restitution, the commodification of culture, and the turn to civil law are all symptoms of this transition. Instances of this relocation of politics include the use of tradition to trump liberal values through the judiciary, the reformulation of political choice into an extension of market choice logics and rights as possessions and objects of wealth. These have become in practice normative structures with violent and unjust consequences for people throughout the African continent and elsewhere (including the so-called North).

Secondly, the authors show how personhood, as an individual project of subject making, is not the European invention that scholars have grown accustomed to invoke. In some African societies, for instance, subjecthood has been historically experienced as a process of constant becoming that involves variegated presentations of the self according to strategic evaluations of contexts and anticipations of future effects. In anthropology, the neoliberal subject has proliferated as a diagnostic used to signal an unprecedented and ongoing historical transformation that from Euro-America has traveled outward. The authors' intervention is to argue that such entity is not as peculiar as scholars have assumed it to be and that the managed self has diverse and multilocal histories. What are anthropologists to do if this central organizing category for asserting Euro-American historical difference is no longer warranted as that which makes Euro-America distinct? How could scholars render the difference the "North" makes legible without the individual possessive subject as marker of its particularity? And, if as the Comaroffs suggest, difference is today a source of unity, what type of subjectivities are anthropologists theoretically equipped to recognize?

Thirdly, the book explores the paradoxical exigencies of openness and closure and life and death as they become simultaneous political and economic ambitions. Subjects are required to bound themselves as individual units while erasing themselves into the collective market; states are required to open up for the flows of commodities and capital while cries for nativism asking for impermeable borders become louder and louder. The United States' backlash against immigrants from Latin America, mostly from Mexico, is a case in point that has been anticipated by South Africa's idiom of aliens, both as plant species and as people from other lands. Yet, the point is not limited to anti-immigrant sentiments, the authors want to show a larger scale phenomenon of rejection of the alien and simultaneous desire for foreign goods [End Page 190] and the complex financial and capital networks that accompany their production. These paradoxical exigencies are experienced also as loss of control over one's labor, something historically tied to the very becoming of individuals into political subjects. Zombies and aliens become figurations of the anxieties that hope and hopelessness create among workers without work; walls and porous borders become symptoms of the spatial impossibility of the neoliberal nation-state. The same paradoxical tension cuts across notions of life and the biopolitical, both marked by the commodity form, as HIV/AIDS remakes citizenship and a sense of political belonging through the mediation of property law. Here the commodity, disease, and the body become magnets of a positive politics that aspires to more than recognition. To become an active member of a community you have to be closer to death. These exigencies push the democratic polis, as a neoliberal collective, to side with a proceduralist logic rather than with a commitment to 
substantial participation in collective decisions. More democracy also means less democracy. [End Page 191] 